\title{
Students' Learning Motivation through the Quality of Scientific Argumentation Skills and Students' Cognitive Learning Outcomes on Newton's Laws: A Relationship Analysis
}

\author{
Almira Betari ${ }^{1 *}$, Alvi Hasanati ${ }^{2}$, Fitroh Fuadah ${ }^{3}$, M. Taufiqurrahman Amir ${ }^{4}$, P. Parno ${ }^{5}$ \\ 1, 2, 3,4 Magister Program of Physics Education, Faculty of Mathematics \& Science, Universitas Negeri Malang, Indonesia \\ ${ }^{5}$ Department of Physics, Faculty of Mathematics \& Science, Universitas Negeri Malang, Indonesia
}

*Corresponding Address: almirabetari@gmail.com

\begin{tabular}{|c|c|}
\hline Article Info & ABSTRACT \\
\hline $\begin{array}{l}\text { Article history: } \\
\text { Received: December } 03^{\text {rd }}, 2020 \\
\text { Accepted: April } 08^{\text {th }}, 2021 \\
\text { Published: April } 30^{\text {th }}, 2021\end{array}$ & $\begin{array}{l}\text { Theory about Newton's Law is considered difficult for students. Many } \\
\text { students cannot solve Newton's Law's problems caused they cannot } \\
\text { understand the concept. Concept understanding requires complex learning } \\
\text { by increasing students' motivation. This study aimed to explore the } \\
\text { relationship between students' motivation through scientific argumentation } \\
\text { skills and students' learning outcomes on Newton's laws. This research was }\end{array}$ \\
\hline $\begin{array}{l}\text { Motivation; } \\
\text { Scientific arguments; } \\
\text { Learning result; } \\
\text { Newton's Law. }\end{array}$ & $\begin{array}{l}\text { a non-experimental mixed-method study with an embedded-correlational } \\
\text { research design. The subjects of this study were } 32 \text { students of Senior High } \\
\text { School (SMA) Laboratory UM Malang (State University of Malang). The } \\
\text { sampling technique used in the study was purposive sampling, specifically } \\
\text { homogeneity sampling. The research instrument consisted of open-ended } \\
\text { questions, semi-structured interviews, questionnaires, and document } \\
\text { identification. The data analysis technique used was a partial correlation test } \\
\text { for quantitative data and descriptive analysis through coding for qualitative } \\
\text { data. The results showed that the quality of students' scientific arguments } \\
\text { was most dominant at Level } 2 \text {. The arguments consisted of claims supported } \\
\text { by data. However, the students sometimes claimed incorrect understanding } \\
\text { of Newton's Laws I and II. The results of the partial correlation test between } \\
\text { motivation and scientific argumentation and student cognitive learning } \\
\text { outcomes did not show any correlation. However, there was a positive } \\
\text { effect. }\end{array}$ \\
\hline
\end{tabular}

(C) 2021 Physics Education Department, UIN Raden Intan Lampung, Indonesia.

\section{INTRODUCTION}

Physics material that analyzes a motion acting on an object is Newton's Law. This material is considered complex material by students (Fadlli et al., 2019). Many students cannot solve problems with Newton's law material. This happens because students do not fully understand the concept (Aryani et al., 2019). When students are assigned to analyze the magnitude of the force exerted by the car and truck when they collide, the student assumes that the force exerted by the truck is greater than the force exerted by the car when they collide (Sari et al., 2020).

The application of Newton's Law is very diverse. For example, the body is pushed back when the car breaks and returns to its original position, the role of the aqua bottle on a slippery floor, the collision between a car and a truck (Sayre et al., 2012; Serway \& Jewett, 2004). The three of them can be analyzed, respectively, through Newton's I, II, and III laws. Therefore, it is essential to understand the concept of Newton's Law so that students can solve problems in everyday life (Murti et al., 2019).

Generally, before learning takes place, students are not in an empty brain state condition. They bring initial knowledge in the form of bits and pieces that they get from previous experiences (Docktor \& Mestre, 2014; Kusnadi et al., 2019; Lee \& 
She, 2010). That piece of knowledge does not fit the theory it should be. So, meaningful learning is needed to change this knowledge.

One indication of meaningful learning is increased student motivation. Increasing student motivation in learning can be done by creating interactions in the learning process, learning resources with the learning environment, and motivating students to participate in the learning process actively (Davidson et al., 2019; Li \& Zheng, 2017; Rutter et al., 2005). However, the reality is that the learning process is still oriented towards the delivery of material and continues with question practice, the lack of interaction between students and students and teachers and students, and the students are not ready to take part in learning, this is evidenced by the fact that there are still students who ignore the teacher and are still busy doing other activities. This fact shows that there is still a lack of students in learning motivation, even though learning motivation plays a significant role in the learning process.

Motivation is an encouragement to do something (Crump, 1995; Fischer \& Horstendahl, 1997; Hakan \& Münire, 2014). Motivation to learn can be interpreted as a conceptual system that changes and changes a person when carrying out learning activities (Rusmono et al., 2018). The learning environment is very influential in learning motivation. Therefore, teachers must create learning that increases student motivation (Abraham \& Barker, 2015). Moreover, motivation can improve students' attitudes and behavior.

Students who are motivated will put in more effort, look for information, and get valid information. Motivation has a positive influence on the learning process to obtain maximum learning outcomes (Saputra et al., 2018). Research by Darmaji (2019) says that students who have learning motivation can improve student learning outcomes (Darmaji et al., 2019; Singh et al., 2002). Besides, motivation also affects student activity in the learning process. If the student's learning motivation is high, the student's activeness will be high too for realize learning achievement (Gunawan, 2018). According to Deng and Yuan (2017), students are more active in selecting and sorting scientific knowledge according to theory (Deng \& Wang, 2017). This is also called scientific argumentation.

Arguments have an essential role in learning activities because they allow students to be involved in groups to express their opinions (Özdem Yilmaz et al., 2017). Scientific argumentation is one way to improve student learning outcomes if low student learning outcomes indicate low scientific argumentation skills (Eliana \& Admoko, 2020). The use of argumentation has many positive effects. These impacts increase conceptual understanding, interest in conducting investigations, representing a result, and skills (Faize et al., 2017; Paramita et al., 2019; Yun \& Kim, 2015). Students can understand a concept with the knowledge they have gotten by themselves based on solid evidence and reasons (Erduran et al., 2019). So that students' memory of this knowledge becomes higher. There are six components to scientific argumentation. These components are claims, data, warrant, backing, qualifier, and rebuttal (Ebadi et al., 2020).

Research that links student motivation to scientific argumentation skills and learning outcomes is still rare. Previous research examined the effect of interest in learning motivation on learning outcomes in physics (Oktalia et al., 2017; Rusmono et al., 2018; Sukma et al., 2016), the relationship between scientific argumentation and student learning outcomes (Sarira et al., 2019). So that further research is needed on the relationship of learning motivation to the quality of scientific argumentation skills and cognitive learning outcomes of students in Newton law material. The research objective was to determine the relationship between learning motivation through the quality of scientific argumentation skills and student 
learning outcomes in Newton's law material.

\section{METHODS}

This research is a non-experimental mixmethod with an embedded-correlational research design. The research objectives determine the relationship of learning motivation to the quality of scientific argumentation skills and student learning outcomes in Newton's law material. The research design was in the form of an explanation (explanatory) to explain the quality of scientific argumentation skills possessed by students. This methodology was used to impart qualitative data to explain the quality of students' scientific argumentation skills deeply. The quantitative data was used to analyze the relationship between the variables studied. The flow of this research design has two components, starting with the quantitative component analyzed using correlational analysis, then implanting the qualitative component with descriptive analysis, which aims to interpret the quantitative results obtained.

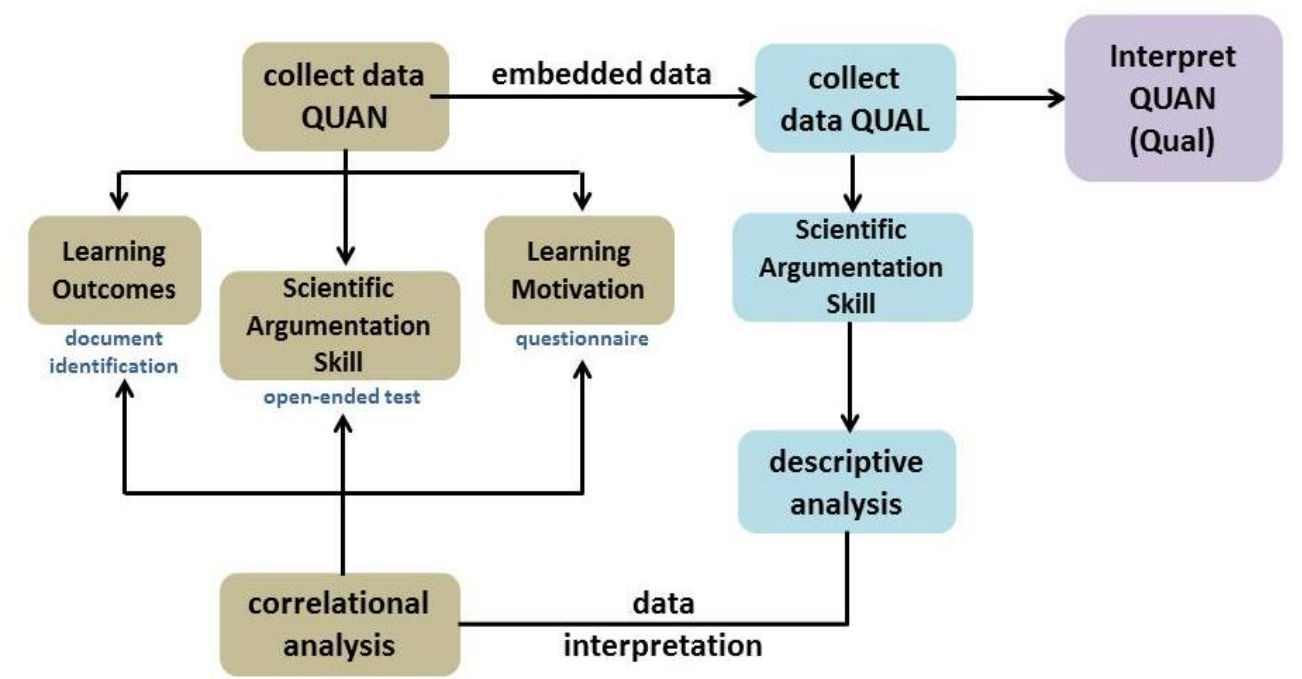

Figure 1. Embedded-Correlational Design

The researchers applied two sampling techniques: quantitative data and qualitative data for quantitative data. The subjects of this study were 32 tenth-grade students of SMA Laboratory UM Malang in the age range of 16-18 years in class. As for qualitative data, purposeful sampling was used to select individuals deliberately based on researchers' estimation. The purposeful sampling used was the homogeneity sampling with sample characteristics of having the same level, being in the same learning environment (following the same physics class), and following the physics material used in the study, namely Newton's Law.

Several data collection methods were used in this study, including filling in open- ended questions, semi-structured interviews, filling out questionnaires, and identifying documents. The open-ended questions aimed to know the quality of students' scientific argumentation skills. The research instrument was adapted from the research conducted by Rahman (2018). This research instrument consisted of two open-ended essay questions (Rahman, 2018). one item discussed Newton's First Law, and the second item discussed Newton's Second Law. The quality of students' scientific argumentation skills was obtained from the essay test results in the form of competing theory. The students were asked to write their scientific argumentation skills on problems related to Newton's First and Second Laws. The quality of students' 
scientific argumentation skills was grouped based on Toulmin's argument pattern. Toulmin's argument pattern consisted of six components: claim, data, warrant, backing, qualifier, and rebuttal. Toulmin's argument pattern was used because this pattern can be applied at all levels of education and is easily compiled by students (Çinar \& Bayraktar, 2014). The argument pattern will be shown based on the answers and arguments of each student categorized in the rubric of the quality of scientific argumentation adapted from (Osborne, 2005; Sampson \& Clark, 2011).

Table 1. Scientific Argument Quality Rubric

\begin{tabular}{ll}
\hline Hierarchy & \multicolumn{1}{c}{ Information } \\
\hline Level 1 & $\begin{array}{l}\text { Simple arguments consist of only } \\
\text { component claims. }\end{array}$ \\
\hline Level 2 & $\begin{array}{l}\text { The arguments consist of components } \\
\text { claim dan data. }\end{array}$ \\
\hline Level 3 & $\begin{array}{l}\text { The arguments consist of components } \\
\text { claim, data, and warrant. }\end{array}$ \\
\hline Level 4 & $\begin{array}{l}\text { The arguments consist of components } \\
\text { claim, data, warrant, and backing. }\end{array}$ \\
\hline Level 5 & $\begin{array}{l}\text { The arguments consist of components } \\
\text { claim, data, warrant, backing, and } \\
\text { rebuttal. }\end{array}$ \\
\hline Level 6 & $\begin{array}{l}\text { Arguments complex of components } \\
\text { claim, data, warrant, backing, } \\
\text { rebuttal, and qualifier capital. }\end{array}$ \\
\hline Source: (Osborme 2005; Sampson \& Clak, 2011)
\end{tabular}

Source: (Osborne, 2005; Sampson \& Clark, 2011)

The following form of data is to conduct semi-structured interviews to dig deeper into the quality of students' scientific arguments based on two physics problems with the content of Newton's laws. Interviews are used in the form of audio recordings regarding the results and process of solving questions related to preparation, difficulty, preparation of arguments, beliefs, and students' conclusions on working on these questions. This semi-structured individual interview took place over time and was dependent on each answer and response. Other forms of data were collected, namely by providing student learning motivation questionnaires. Researchers compiled this questionnaire through expert validity, aiming to determine student learning motivation in the learning process. Then, the final form of data is the identification of documents on student cognitive learning outcomes from the list of student final semester test scores.

The forms of data collection are carried out in turns, where the form of quantitative data becomes the focal point of the research. The quantitative data then analyzed the correlation of the relationship between variables that were then implanted with qualitative data to describe the quality of students' scientific argumentation skills obtained from the form of open test data and interviews. The quantitative data analysis technique used in this research was a partial correlation test. Meanwhile, qualitative data used descriptive analysis by transcribing data coding.

\section{RESULTS AND DISCUSSION}

The material used in the study was Newton's Law. The value data of learning motivation were obtained from a test instrument in the form of a statement questionnaire totaling 24 statement items.

Based on Table 2, the students' physics learning motivation's lowest and highest values were 52 and 94 . The average value of students' physics learning motivation is 75.52 , the standard deviation is 9,631, and the variance is 92,756 . Based on the data in Figure 2 and Table 2. It can be concluded that the students' was good. 


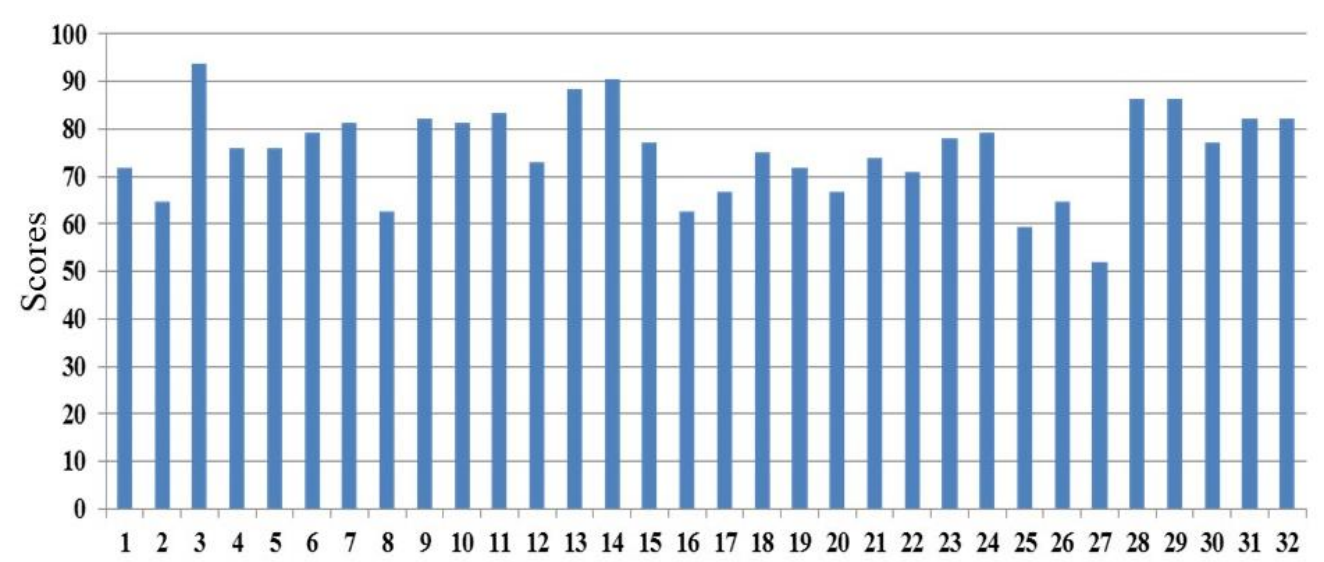

Figure 2. Physics Learning Motivation

Slameto (1995) states that learning motivation is influenced by three components: (1) cognitive encouragement, namely the need to know, understand, and solve problems. This impulse arises in the process of interaction between students and assignments or problems; (2) self-esteem, that is, some sure students are diligent in learning and carry out tasks not primarily to gain knowledge or skills, but to gain status and self-respect; and (3) the need for affiliation, namely the need to master learning materials or study to obtain justification from other people or friends. This need is challenging to separate from self-respect.

Table 2. Descriptive Analysis of the Value of the Learning Motivation in Physics.

\begin{tabular}{cc}
\hline Descriptive Analysis & $\begin{array}{c}\text { Physics Learning } \\
\text { Motivation }\end{array}$ \\
\hline Total Student & 32 \\
\hline Standard Deviation & 9.631 \\
\hline Minimum Score & 52 \\
\hline Maximum Score & 94 \\
\hline Variance & 92.756 \\
\hline Average & 75.52 \\
\hline
\end{tabular}

The research results indicated that the cognitive learning outcome data obtained from the test instrument in multiple-choice questions totaling 21 items. Students' cognitive learning outcomes demonstrated in the form of a diagram are presented in Figure 3 and Table 3.

Table 3. Descriptive Analysis of Cognitive Learning Outcomes

\begin{tabular}{cc}
\hline $\begin{array}{c}\text { Descriptive } \\
\text { Analysis }\end{array}$ & $\begin{array}{c}\text { Learning Outcomes } \\
\text { Cognitive }\end{array}$ \\
\hline Total Students & 32 \\
\hline Standard Deviation & 8.842 \\
\hline Minimum Score & 37 \\
\hline Maximum Score & 76 \\
\hline Variance & 78.190 \\
\hline average & 59.94 \\
\hline
\end{tabular}

Based on Table 3, it appears that students' cognitive achievement in a sequence of the lowest and the highest was 37 and 76. The average value -The mean of students' cognitive learning outcomes was 59.94, the standard deviation was 8.842, and the variance was 78,190 . Based on the data in Figure 3. and Table 3. It can be concluded that the student's cognitive learning outcomes were moderate.

According to Slameto (1995: 54), several factors affect student cognitive learning outcomes, namely (1) intelligence; (2) attention; (3) interest; (4) talent; (5) mobility to carry out activities; (6) maturity; and (7) readiness. At the same time, the external factors are family, school, and the surrounding environment. 


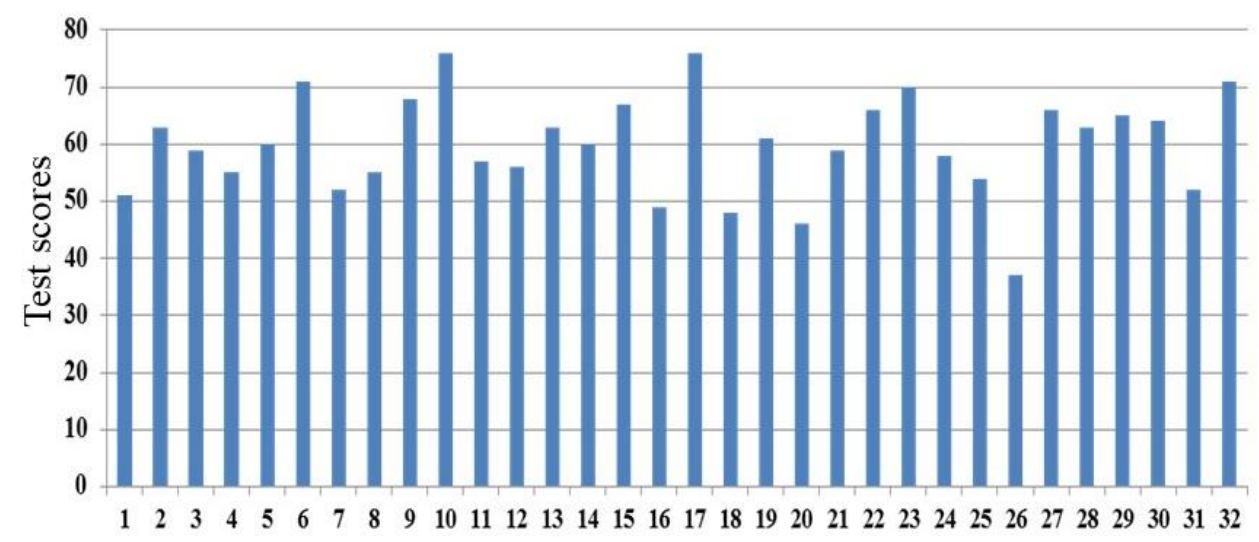

Figure 3. Students' Cognitive Learning Outcomes

Ability student's scientific arguments derived from questions about Newton's Law of matter and the Law II Newton. The problem given is only one item, namely the first item in Newton's Law I. This item discusses Newton's First Law application to objects at rest or moving straight in the inertia frame of reference. The quality of students' scientific argumentation skills on Newton's First Law can be seen in Figure 4.

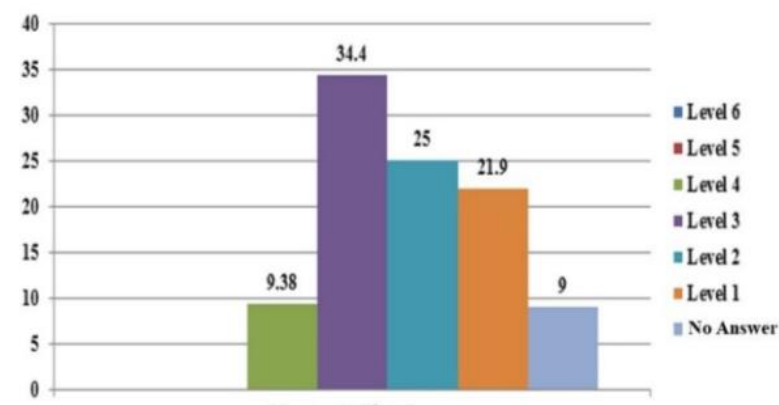

Figure 4. The Quality of Scientific Argumentation Skills in Newton's First Law Material

Based on Figure 4. it appears that the percentage of the quality of students' scientific argumentation skills in order from the largest is Level 3 (34.4\%), Level 2 (25.0\%), Level 1 (21.9\%), Level 4, and no answer (9.4\%), and Level 5 and Level 6 $(0.0 \%)$. There are no students who have the quality of scientific argumentation skills at Level 5 and Level 6. Based on the data in Figure 4, the quality of students' scientific argumentation skills on Newton's First Law was moderate.

The cause of students 'difficulties in developing arguments on Newton's First and
Second Laws material is due to the lack of students' knowledge of essential concepts related to Newton's First and Second Laws. The quality of students' scientific argumentation skills can be improved by integrating argumentation activities into Newton's Law I and II learning. Ivan and Niko were at Malang train station waiting
for their train. They saw Rama sitting in the train
when it stopped. Rama walked to the front car at a
speed of $1 \mathrm{~m} / \mathrm{s}$. Ivan and Nico agreed that Rama
walked at the speed of $1 \mathrm{~m} / \mathrm{s}$. A moment later the train
started running at $8 \mathrm{~m} / \mathrm{s}$ in the same direction as
Rama. Based on their observation, they started
having a conversation about Rama's walking speed.
Ivan: "I believe that Rama is walking at $1 \mathrm{~m} / \mathrm{s}$ "
Nico: "why? I believe that Rama is walking at $9 \mathrm{~m} / \mathrm{s}$ "
Based on the discussion, create an argument if you
agreed with Ivan, Nico, or neither of them. Complete
your argument with valid reasons.

Figure 5. Item of Newton's First Law Problem

Items on Newton's First Law discussing the application of Newton's First Law to objects that are at rest or moving straight on the inertial frame of reference can be seen in Figure 5.

Examples of student answers to this item are as follows.

Example 1: "I agree with Ivan's opinion. Because indeed Rama's speed is $1 \mathrm{~m} / \mathrm{s}$. "

Example 2: "I agree with Ivan's opinion. Because the speed of the train does not affect the speed of the objects/people in it. " 
Example 3: "I agree with Ivan's opinion. Because Rama walked in the train and only moved to another place but was still on the train and the train went in the same direction as Rama, who was walking on the train. (Rama runs towards the training room while the train moves towards the station). "

Example 4: "I agree with Ivan's opinion. Because from the information above, it was clear when Rama walked with $1 \mathrm{~m} / \mathrm{s}$. So, even though the train was traveling at $8 \mathrm{~m} /$ $\mathrm{s}$, Rama was still running at $1 \mathrm{~m} / \mathrm{s}$ because he is walking on the train. Furthermore, what was being asked was not the speed of the train but the speed of Rama. Moreover, the road speed of Rama with the train is not related ".

The student's argument in example 1 is included in the quality of scientific argumentation skills at Level 1 because the student's answer consists of only one claim (in Table 1). In this example, students do not try to give convincing reasons to support their claim with data, warrant, or backing. The student's argument in example 2 consists of a clerk equipped with data, so the student has the quality of scientific argumentation skills at Level 2, and the student's argument in example 3 has a C2WD argument pattern so that it is included in the quality of scientific argumentation skills at Level 3. The students' arguments in examples 2 and 3, although they have different argument components to support claims, do not complete their arguments with backing or rebuttal. This shows that students only use data that supports the claims they make. Meanwhile, in the students' arguments in example 4, the arguments made by students appear more complex. They have backed with support information of the data and warrant to be included in the quality of scientific argumentation skills at Level 4.

Based on Newton's First Law items, it appears that students tend to agree with the opinion using the train's frame of reference.
Students seem to be more familiar with the train as a frame of reference for identifying Rama's speed. Students do not review Nico's opinion at all, where Nico's opinion can be the correct opinion according to Newton's First Law if the case of Rama's motion is viewed from the ground as a frame of reference. Students also do not complete their answers with backing, namely Newton's First Law, which explains the definition of a frame of reference when an object is at rest or moving straight at a constant speed. However, implicitly this appears in the student's answer in example 3.

Problem with Newton's Second Law of material there is only one item question is the second item. These items discuss acceleration, force, and mass. The quality of students' scientific argumentation skills on Newton's Second Law can be seen in Figure 5 . The percentage of the quality of students' scientific argumentation skills in order from the largest is Level $2(53,1 \%)$, Level 4 $(31.3 \%)$, Level 3 (12.5\%), no answer (3.0\%), and Level 1, Level 4, and Level 5 $(0.0 \%)$. No student had Level 1, 5, and 6 argumentation skills. Thus, it can be concluded that the quality of scientific argumentation skills was low.

Newton's Second Law discussed acceleration, force, and mass, as shown in Figure 7.

Examples of student answers to this item are as follows.

Example 1: "I agree with Farrell's opinion. Because the more significant the force exerted, the same acceleration on the cart will be. "

Example 2: "I agree with Farrell's opinion because the force that is given will affect acceleration."

Example 3: "I agree with Farrell's opinion. The force applied will be directly proportional to the acceleration. If the acceleration of the object's motion is great, then the force will be great resulting from." 


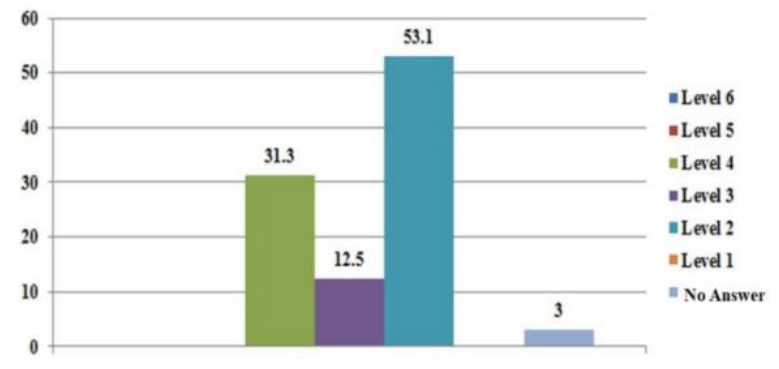

Figure 6. The Quality of Scientific Argumentation Skills on Newton's Second Law Material

The student's argument in example 1 is included in the argument with the quality of scientific argumentation skills at Level 2. This is because there are claims that are equipped with data. In the student's argument in example 2, the quality of the students' scientific argumentation skills is at Level 3. Because in example 2, students begin to show the relationship between force and acceleration as a warrant for the claims they make. The student's argument in example 3 includes arguments with the quality of scientific argumentation skills at Level 4. This student's argument is equipped with backing and warrant to support the claim he makes. Students do not write down Newton's Second Law equation explicitly but express it with written representations.

$\begin{aligned} & \text { Farel and Ganesha is looking at Mr. Ahmad who is } \\ & \text { pushing his cart. Then, they are having a discussion } \\ & \text { about the cart's accelaration. } \\ & \text { Farel: If Mr. Ahmad's thrust is bigger, then the } \\ & \text { cart's accelaration will also be bigger. What } \\ & \text { do you think, Ganesha? }\end{aligned}$
Ganesha: I think, the bigger the thrust, the smaller
the accelaration will be.
$\begin{aligned} & \text { Based on the discussion, construct an argument if } \\ & \text { you are agree with Farel, Ganesha, or neither of } \\ & \text { them. Complete your argument with convincing } \\ & \text { evedence. }\end{aligned}$

Figure 7. Item of Newton's Law II Problem

Based on students' arguments against the items about Newton's Second Law, students tend to only strengthen their claims by explaining why they agree with Farrell's opinion and ignore Ganesha's opinion.
Students do not try to complete their arguments with a rebuttal about Ganesha's opinion. This shows that students are still included in the low group in arguing.

The correlation test aimed to determine whether there was a positive or negative relationship between the physics learning motivation and the quality of scientific argumentation skills and student cognitive learning outcomes. The correlation test used was the Test of Partial Correlation with a significant level of $\alpha=0.05$ assisted by SPSS Release-16.0. The decision-making criteria are as follows.

- If the value (significance (2-tailed) Correlations) $<0.05$, then the is a correlation.

- If the value (significance (2-tailed) Correlations) $>0.05$, then is no correlation.

Table 4. Correlation between Variable

\begin{tabular}{ccccc} 
Control & & $\begin{array}{c}\text { Scientific } \\
\text { Argument } \\
\text { Variables }\end{array}$ & $\begin{array}{c}\text { Cognitive } \\
\text { Quality } \\
\text { Skills }\end{array}$ & $\begin{array}{c}\text { Learning } \\
\text { Outcome } \\
\text { s }\end{array}$ \\
\hline & & & \\
Quality Skills & Cor & 1.000 & 0.181 \\
Argument & Sig & & 0.312 \\
Scientific & df & 0 & 31 \\
\cline { 2 - 5 } & Learning & Cor & 0.181 & 1.000 \\
Outcomes & Sig & 0.312 & \\
Cognitive & df & 31 & 0 \\
\hline
\end{tabular}

Based on Table 4, the obtained value was 0.312 . Therefore, it can be concluded that there was no correlation between the value of learning motivation in physics on the quality of scientific argumentation skills. Students' cognitive learning, but there is a positive influence among them. Meanwhile, for the correlation criteria, the value is Correlation 0.181 , so the correlation criterion does not exist.

The research results showed that the average quality of students' scientific argumentation skills was still at Level 2. Namely, the arguments only consisted of components claim and data. This is partly because, in the learning process, the teacher does not apply a model or learning method based on scientific argumentation in his 
science class and does not facilitate students in developing their arguments. However, the teacher focuses on integrated learning and object-free diagrams in Newton's Law I and II material and uses the methods of learning lectures, discussions, questions and answers, and presentations. Students also do not explore their potential independently in arguing during the learning process, so the result is that the quality of scientific argumentation skills of the tenth-grade students of SMA Laboratorium UM Malang on Newton's first and second Law was low.

The results showed that the quality of students' scientific argumentation skills on Newton's Law I and II material was still in the low category. The data shows that most students have the quality of scientific argumentation skills at Level 1, Level 2, and Level 3. At level 2, many students give reasons for the claims they make by repeating the statements contained in the items. As a result, students do not provide proper reasons to support their claims but only confirm the claims they make with other claims. The results of this study are in line with other studies where students do not build warrants to support claims made or provide an explanation of the problems given (Eskin \& Ogan-Bekiroglu, 2013; Ju et al., 2017).

The low quality of students' arguments on Newton's Law material can be seen from three things. First, based on the argument pattern made by students, it shows that students do not understand well the components of an argument. The correct argument consists of a claim that is accompanied by a basis, and an argument that is not accompanied by a warrant is not reasonable (Rapanta et al., 2013). This shows that students do not understand how to give a warrant proper to support their claim. Second, students tend only to use data that supports the claims they make (Sampson \& Clark, 2011). Students make arguments that contain a small portion of the content of the given item and are unable to fulfill the request of the given item
(Aufschnaiter et al., 2008). Third, the knowledge possessed by students affects the arguments prepared by students. Knowledgeable students will develop higher-quality arguments (Hakyolu \& Ogan-Bekiroglu, 2016; Kutluca et al., 2013; Ogan-Bekiroglu \& Eskin, 2012).

Students need to understand how to compile quality arguments on Newton's First and Second Laws material. However, based on the results of this study, it appears that students cannot compile quality arguments related to Newton's Law. Most students had difficulty in compiling quality arguments. Besides, the highest quality of students' scientific argumentation skills was at Levels 1, 2, and 3. This study is in line with the research of Ju, et al. (2017), which shows that the quality of students' scientific argumentation skills dominantly at Level 1, where students tend to make claims without proper justification or do not give warrant to link claims with data.

The low quality of students' scientific argumentation skills can be overcome by integrating argumentation activities into Newton's Law learning. Learning that involves argumentation will facilitate student involvement in compiling complex arguments of higher quality (Acar \& Patton, 2012; Aufschnaiter et al., 2008; Berland \& McNeill, 2010; Kind et al., 2011; Osborne, 2005; Rapanta et al., 2013). More and more students gain experience with concepts during argumentation. The students are increasingly producing argumentation components, including rebuttal quality (Ogan-Bekiroglu \& Eskin, 2012).

The integration of argumentation into learning activities can be done in various ways, including argumentation sessions into learning activities (Oh \& Jonassen, 2007) or practicum (Eskin \& Ogan-Bekiroglu, 2013; Sekerci \& Canpolat, 2017; Wang \& Buck, 2015) or implementing learning with an argumentation-based learning model (Sampson et al., 2013; Sampson \& Clark, 2011; Walker \& Sampson, 2013; Yaman, 2018). In addition, students can also 
improve their ability to argue by defending and evaluating claims made by peers (Sekerci \& Canpolat, 2017). Thus, if physics learning in SMA Laboratorium UM is integrated into learning in the way previously described, then the quality of students' scientific argumentation skills can be more than level 2 .

\section{CONCLUSION}

The quality of students' scientific argumentation skills on Newton's Law I and II material is still low. The students' scientific arguments are still at Level 2. The cause of the students' difficulties is the students' knowledge of essential concepts related to Newton's First and Second Laws. The quality of students' scientific argumentation skills can be improved by integrating argumentation activities into Newton's Law I and II learning. The relationship between variables shows that there are no variables, but there are influences between variables.

Students' argumentative skills should be developed with argumentation-based learning to learn Newton's first and second law concepts for teachers. Suggestions for further researchers are research that can be carried out on Newton III Law material regarding the quality of students' scientific argumentation skills. In addition, further research can be carried out on providing stimulus to students in learning activities by involving argumentation activities to be motivated to develop quality arguments and increase learning outcomes.

\section{ACKNOWLEDGMENTS}

The researchers would like to thank the supervisors for their guidance and direction. The researchers also express their gratitude to the principal and science teacher at SMA Laboratorium UM Malang for their assistance in carrying out this research.

\section{REFERENCES}

Abraham, J., \& Barker, K. (2015). Exploring gender difference in motivation, engagement, and enrolment behavior of senior secondary physics students in new south wales. Research in Science Education, 45(1), 59-73. https://doi.org/10.1007/s11165-0149413-2

Acar, O., \& Patton, B. R. (2012). Argumentation and formal reasoning skills in an argumentation-based guided inquiry course. Procedia Social and Behavioral Sciences, 46, 4756-4760.

https://doi.org/10.1016/j.sbspro.2012 .06 .331

Aryani, W. D., Suhendi, E., Suyana, I., Samsudin, A., \& Kaniawati, I. (2019). Effectiveness of implementation interactive conceptual instruction (ICI) with computer simulation to overcome students' misconceptions about newton's Law of gravitation. Journal of Physics: Conference Series, 1280(1), 1-7. https://doi.org/10.1088/17426596/1280/5/052011

Aufschnaiter, C. V., Erduran, S., Osborne, J., \& Simon, S. (2008). Arguing to learn and learning to argue: Case studies of how students' argumentation relates to their scientific knowledge. Journal of Research in Science Teaching, 45(1), 101-131.

https://doi.org/10.1002/tea.20213

Berland, L. K., \& McNeill, K. L. (2010). A learning progression for scientific argumentation: Understanding student work and designing supportive instructional contexts: Learning progression for scientific argumentation. Science Education, 94(5), 765-793. https://doi.org/10.1002/sce.20402

Çinar, D., \& Bayraktar, Ş. (2014). Evaluation of the effects of argumentation-based science teaching on 5th-grade students' 
conceptual understanding of the subjects related to "matter and change." International Journal of Education in Mathematics, Science and Technology, 2(1), 49-77.

Crump, C. A. (1995). Motivating students: A teacher's challenge. West Texas A\&M University, 1-21.

Darmaji, D., Astalini, A., Kurniawan, D. A., \& Perdana, R. (2019). A study relationship attitude toward physics, motivation, and character discipline students senior high school, in Indonesia. International Journal of Learning and Teaching, 11(3), 99109.

https://doi.org/10.18844/ijlt.v11i3.42 07

Davidson, P., Roslan, S., Omar, Z., Chong Abdullah, M., Looi, S. Y., Neik, T. T. X., \& Yong, B. (2019). Validation of competing structural models of inter-relationships in the teachinglearning ecosystem for two Malaysian STEM courses. Asia Pacific Education Review, 20(1), 15-36.

https://doi.org/10.1007/s12564-0189567-0

Deng, Y., \& Wang, H. (2017). Research on evaluation of Chinese students' competence in written scientific argumentation in the context of chemistry. Chemistry Education Research and Practice, 18(1), 127150.

https://doi.org/10.1039/C6RP00076 B

Docktor, J. L., \& Mestre, J. P. (2014). Synthesis of discipline-based education research in physics. Physical Review Special Topics Physics Education Research, 10(2), 020119.

https://doi.org/10.1103/PhysRevSTP ER.10.020119

Ebadi, S., Ashtarian, S., \& Zamani, G. (2020). Exploring arguments presented in predatory journals using toulmin's model of argumentation. Journal of Academic Ethics, 18(4), 435-449.

https://doi.org/10.1007/s10805-01909346-0

Eliana, D., \& Admoko, S. (2020). Tren pembelajaran argumentasi berbasis toulmin's argument pattern (TAP) dalam meningkatkan kemampuan argumentasi dan pemahaman konsep fisika peserta didik. IPF: Inovasi Pendidikan Fisika, 09(02), 246-255.

Erduran, S., Guilfoyle, L., Park, W., Chan, J., \& Fancourt, N. (2019). Argumentation and interdisciplinarity: Reflections from the Oxford argumentation in religion and science project. Disciplinary and Interdisciplinary Science Education Research, 1(1), 1-10. https://doi.org/10.1186/s43031-0190006-9

Eskin, H., \& Ogan-Bekiroglu, F. (2013). Argumentation as a strategy for conceptual learning of dynamics. Research in Science Education, 43(5), 1939-1956. https://doi.org/10.1007/s11165-0129339-5

Fadlli, M. R., Sutopo, \& Wartono. (2019). Analisis kesulitan siswa dalam menyelesaikan soal hukum newton. Jurnal Pendidikan: Teori, Penelitian, dan Pengembangan, 4(8), 993-997. http://dx.doi.org/10.17977/jptpp.v4i8 .12652

Faize, F. A., Husain, W., \& Nisar, F. (2017). A Critical review of scientific argumentation in science education. EURASIA Journal of Mathematics, Science and Technology Education, 14(1), 475-483. https://doi.org/10.12973/ejmste/8035 3

Fischer, H. E., \& Horstendahl, M. (1997). Motivation and learning physics. Research in Science Education, 
27(3),

411-424.

https://doi.org/10.1007/BF02461762

Gunawan, Y. I. P. (2018). Pengaruh motivasi belajar terhadap keaktifan siswa dalam mewujudkan prestasi belajar siswa. Khazanah Akademia, 02(01), 74-84.

Hakan, K., \& Münire, E. (2014). Academic motivation: Gender, domain and grade differences. Procedia - Social and Behavioral Sciences, 143, 708715.

https://doi.org/10.1016/j.sbspro.2014 .07 .469

Hakyolu, H., \& Ogan-Bekiroglu, F. (2016). Interplay between content knowledge and scientific argumentation. EURASIA Journal of Mathematics, Science and Technology Education, 12(12), 3005-3033.

https://doi.org/10.12973/eurasia.201 6.02319a

Ju, H., Choi, I., \& Yoon, B. Y. (2017). Do medical students generate sound arguments during small group discussions in problem-based learning?: An analysis of preclinical medical students' argumentation according to a framework of hypothetico-deductive reasoning. Korean Journal of Medical Education, 29(2), 101-109. https://doi.org/10.3946/kjme.2017.57

Kind, P. M., Kind, V., Hofstein, A., \& Wilson, J. (2011). Peer argumentation in the school science laboratory-Exploring effects of task features. International Journal of Science Education, 33(18), 25272558.

https://doi.org/10.1080/09500693.20 10.550952

Kusnadi, K., Lazuardi, Z., \& Surakusumah, W. (2019). The Conceptual change of human respiratory system through POE-Based learning. Journal of Physics: Conference Series, 1280(3),
1-6. https://doi.org/10.1088/17426596/1280/3/032009

Kutluca, A. Y., Çetin, P. S., \& Doğan, N. (2013). Effect of content knowledge on scientific argumentation quality: Cloning context. Necatibey Faculty of Education Electronic Journal of Science and Mathematics Education, $8(1)$, $1-30$. https://doi.org/10.12973/nefmed.201 4.8.1.a1

Lee, C.-Q., \& She, H.-C. (2010). Facilitating students' conceptual change and scientific reasoning involving the unit of Combustion. Research in Science Education, 40(4), 479-504. https://doi.org/10.1007/s11165-0099130-4

Li, S., \& Zheng, J. (2017). The effect of academic motivation on students' English learning achievement in the eSchoolbag-based learning environment. Smart Learning Environments, 4(1), 1-14. https://doi.org/10.1186/s40561-0170042-x

Murti, P. R., Aminah, N. S., \& Harjana. (2019). The identification of high school students' knowledge of newton's Law of science literacy using a test based on nature of science (NOS). Journal of Physics: Conference Series, 1153(1), 012122. https://doi.org/10.1088/17426596/1153/1/012122

Ogan-Bekiroglu, F., \& Eskin, H. (2012). Examination of the relationship between engagement in scientific argumentation and conceptual knowledge. International Journal of Science and Mathematics Education, 10(6), 1415-1443. https://doi.org/10.1007/s10763-0129346-z

Oh, S., \& Jonassen, D. H. (2007). Scaffolding online argumentation during problem solving: Scaffolding online argumentation. Journal of Computer Assisted Learning, 23(2), 
95-110.

https://doi.org/10.1111/j.1365-

2729.2006.00206.X

Oktalia, Y., Sakti, I., \& Hamdani, D. (2017). Pengaruh minat dan motivasi pada penerapan model diskoveri berbantuan media animasi terhadap hasil belajar fisika di SMA negeri 4 Kota Bengkulu. Jurnal Pembelajaran Fisika, 1(1), 87-95.

Osborne, J. (2005). The role of argument in science education. In K. Boersma, M. Goedhart, O. de Jong, \& H. Eijkelhof (Eds.), Research and the Quality of Science Education ( $p p$. 367-380). Springer Netherlands. https://doi.org/10.1007/1-4020-36736_29

Özdem Yilmaz, Y., Cakiroglu, J., Ertepinar, H., \& Erduran, S. (2017). The pedagogy of argumentation in science education: Science teachers' instructional practices. International Journal of Science Education, 39(11), 1443-1464. https://doi.org/10.1080/09500693.20 17.1336807

Paramita, A., Dasna, I. W., \& Yahmin, Y. (2019). Kajian pustaka: Integrasi stem untuk keterampilan argumentasi dalam pembelajaran sains. J-PEK (Jurnal Pembelajaran Kimia), 4(2), 92-99. https://doi.org/10.17977/um026v4i2 2019p092

Rahman, A. (2018). Kemampuan argumentasi ilmiah dan penguasaan konsep materi hukum Newton siswa kelas X SMA Kota Banjarmasin. Skripsi. Universitas Negeri Malang.

Rapanta, C., Garcia-Mila, M., \& Gilabert, S. (2013). What is meant by argumentative competence? An integrative review of methods of analysis and assessment in education. Review of Educational Research, 83(4), 483-520. https://doi.org/10.3102/00346543134 87606
Rusmono, R., Sulardi, S., \& Suyitno, S. (2018). Influence of learning model and learning motivation to learning outcome of micro hydropower plant. IOP Conference Series: Materials Science and Engineering, 434(1), 012028. https://doi.org/10.1088/1757899X/434/1/012028

Rutter, K. L., Smith, B. P., \& Hall, H. C. (2005). The effects of gender and grade level on the motivational needs of family and consumer sciences students. Journal of Family and Consumer Sciences Education, 23(2), 19-26.

Sampson, V., \& Clark, D. B. (2011). A comparison of the collaborative scientific argumentation practices of two high and two low performing groups. Research in Science Education, 41(1), 63-97. https://doi.org/10.1007/s11165-0099146-9

Sampson, V., Enderle, P., Grooms, J., \& Witte, S. (2013). Writing to learn by learning to write during the school science laboratory: Helping middle and high school students develop argumentative writing skills as they learn core ideas: Writing to learn by learning to write in science. Science Education, 97(5), 643-670. https://doi.org/10.1002/sce.21069

Saputra, H. D., Ismet, F., \& Andrizal, A. (2018). Pengaruh motivasi terhadap hasil belajar siswa SMK. INVOTEK: Jurnal Inovasi Vokasional dan Teknologi, 18(1), 25-30. https://doi.org/10.24036/invotek.v18 i1.168

Sari, N., Murniati, \& Ilyas, S. (2020). The implementation of problem-based learning modules to decrease misconception on Newton's law topic. Journal of Physics: Conference Series, 1460(1), 012137. https://doi.org/10.1088/17426596/1460/1/012137 
Sarira, P. M., Priyayi, D. F., \& Astuti, S. P. (2019). Hubungan argumentasi ilmiah dan hasil belajar kognitif pada penerapan model problem based learning (PBL). Edu Sains Jurnal Pendidikan Sains \& Matematika, 7(2), $1-10$. https://doi.org/10.23971/eds.v7i2.12 58

Sayre, E. C., Franklin, S. V., Dymek, S., Clark, J., \& Sun, Y. (2012). Learning, retention, and forgetting of newton's third law throughout university physics. Physical Review Special Topics - Physics Education Research, $\quad 8(1), \quad 010116$. https://doi.org/10.1103/PhysRevSTP ER.8.010116

Sekerci, A. R., \& Canpolat, N. (2017). Argumentation skills of Turkish freshman university students in chemistry laboratory. Journal of Educational Sciences \& Psychology, 7(1), 26-39.

Serway, R. A., \& Jewett, J. W. (2004). Physics for scientists and engineers (6th ed). Thomson-Brooks/Cole.

Singh, K., Granville, M., \& Dika, S. (2002). Mathematics and science achievement: Effects of motivation, interest, and academic engagement. The Journal of Educational Research, 95(6), 323-332. https://doi.org/10.1080/00220670209 596607

Sukma, Komariyah, L., \& Syam, M. (2016). Pengaruh model pembelajaran inkuiri terbimbing (Guided inquiry) dan motivasi terhadap hasil belajar fisika siswa pengaruh model pembelajaran inkuiri terbimbing (guided inquiry) dan motivasi terhadap hasil belajar fisika siswa. Saintifika, 18(1), 49-63.

Walker, J. P., \& Sampson, V. (2013). Learning to argue and arguing to learn: Argument-driven inquiry as a way to help undergraduate chemistry students learn how to construct arguments and engage in argumentation during a laboratory course: Learning to argue and arguing to learn. Journal of Research in Science Teaching, 50(5), 561596.

https://doi.org/10.1002/tea.21082

Wang, J., \& Buck, G. (2015). The relationship between chinese students' subject matter knowledge and argumentation pedagogy. International Journal of Science Education, 37(2), 340-366. https://doi.org/10.1080/09500693.20 14.987713

Yaman, F. (2018). Effects of the science writing heuristic approach on the quality of prospective science teachers' argumentative writing and their understanding of scientific argumentation. International Journal of Science and Mathematics Education, 16(3), 421-442. https://doi.org/10.1007/s10763-0169788-9

Yun, S. M., \& Kim, H.-B. (2015). Changes in students' participation and small group norms in scientific argumentation. Research in Science Education, 45(3), 465-484. https://doi.org/10.1007/s11165-0149432-z 